\title{
CADMIUM-INDUCED CHANGES IN GROWTH AND MICRONUTRIENT COMPOSITION OF TWO PEPPER CULTIVARS
}

\author{
BARUT, $\mathrm{H}$. \\ East Mediterranean Agricultural Research Institute, 01321 Adana, Turkey \\ (e-mail: barut.hatun.hb@gmail.com; phone: +90-322-334-0055) \\ (Received $8^{\text {th }}$ Dec 2018; accepted $28^{\text {th }}$ Jan 2019)
}

\begin{abstract}
The present research was conducted to investigate the effects of cadmium (Cd) treatments on shoot and root dry weight, SPAD values, shoot and root $\mathrm{Cd}$ accumulations and micronutrient compositions of two pepper cultivars (Capsicum annиum L. cvs. 'Demre' and 'AT58'). Plants were grown under controlled conditions with 0 and $15 \mu \mathrm{M} \mathrm{Cd}$ supplies. Decreasing root and shoot dry weights were observed with increasing $\mathrm{Cd}$ doses $(\mathrm{P}<0.05)$. Decrease in shoot and root dry weights with $15 \mu \mathrm{M}$ Cd supply was higher in Demre cultivar than in AT58 cultivar. Cd-induced decreases in SPAD values were greater in Demre cultivar than in AT58 cultivar. Shoot Cd concentrations were lower and root Cd concentrations were greater in AT58 cultivar than in Demre cultivar. Decreasing shoot zinc (Zn), iron $(\mathrm{Fe})$, manganese $(\mathrm{Mn})$ and copper $(\mathrm{Cu})$ concentrations and root $\mathrm{Zn}$ and $\mathrm{Mn}$ concentrations were observed with $\mathrm{Cd}$ treatments. Considering the $\mathrm{Cd}$ uptake and transport to shoot, it was observed that there were differences in tolerance of cultivars to Cd toxicity, but it was thought that these differences were not necessarily related to microelement uptake and transport of the cultivars.
\end{abstract}

Keywords: heavy metal, SPAD value, zinc, iron, manganese, copper

\section{Introduction}

Cadmium (Cd) is a highly toxic heavy metal and poses significant threats to human health and environment. Developed industrial and agricultural practices lead to significant increases in soil cadmium levels (Sarwar et al., 2010). Phosphorus fertilizers, Cd-containing wastewater treatment sludge, livestock manure, wastewater effluents, various metal processing industries, cement facilities and urban traffic are considered to be the greatest sources of Cd for soil (Alloway and Steinnes, 1999; Yang et al., 2004). Although cadmium is not considered as an essential nutrient for plants, soil available $\mathrm{Cd}$ is easily up taken through the roots and accumulated in the plant tissues and pose serious health risks on humans through the food chain (Zhou and Qiu, 2005). High cadmium concentrations also damage plant roots, destruct photosynthetic activity, recess plant growth and development and hinder plant nutrient and water uptake from the soil (Jibril et al., 2017). High cadmium levels influence cell membrane permeability (Sengar et al., 2008) and destruct antioxidant defense mechanisms of the plants against oxidative stress conditions through elevated lipid peroxidation (Benavides et al., 2005).

Plant normal cadmium concentrations were reported as between $0.2-0.8 \mathrm{mg} \mathrm{kg}^{-1}$ and toxic levels as between 5-30 $\mathrm{mg} \mathrm{kg}^{-1}$ (Allen, 1989; Kloke et al., 1984). Similar with the other stressors, $\mathrm{Cd}$ also hinders plant nutrient uptake, interacts with the soil available nutrients and ultimately results in imbalanced mineral nutrition (Khan et al., 2007). There is a great competition between $\mathrm{Cd}$ ions and the other essential plant nutrients including $\mathrm{Ca}, \mathrm{Mg}, \mathrm{K}, \mathrm{Cu}, \mathrm{Zn}, \mathrm{Fe}, \mathrm{Ni}$ and $\mathrm{Mn}$ required for plant growth and development (Clarkson and Luttge, 1989; Rivetta et al., 1997). In a previous study, either synergistic or antagonistic effects of cadmium were reported on plant nutrients (macro or micro) of different wheat cultivars (Zhang and Huang, 2000). In other studies, either negative 
(Bhandal and Kuar, 1992) or positive (Mitchel et al., 2000) correlations of cadmium were reported with nitrogen. Similarly, antagonistic (Li et al., 1990) and synergistic (Nan et al., 2002) interactions of cadmium were reported with zinc. Cadmium treatments increased $\mathrm{Cu}$ and Mo levels and decreased $\mathrm{K}, \mathrm{Ca}, \mathrm{Mg}$ and $\mathrm{Mn}$ levels of Birch seedlings (Gussarsson, 1994). Increasing Cd levels resulted in greater $\mathrm{Cd}, \mathrm{Zn}, \mathrm{Fe}, \mathrm{Mn}$ and $\mathrm{Cu}$ accumulations in roots and slight $\mathrm{Cd}$ transfer to shoots (Wang et al., 2007).

Different plants have various cadmium accumulation capacities (Yang et al., 1996; Obata and Umebayashi, 1997; Yildiz, 2005). However, variations were also reported among the different cultivars of wheat (Naeem et al., 2016), barley (Tiryakioglu et al., 2006), maize (Ekmekci et al., 2008), soybeans (Shamsi et al., 2008), tomato (Hussain et al., 2015) and chilli peppers (Xin et al., 2013). Kuboi et al. (1986) classified Cd accumulation capability of the plants into three groups (high, moderate and low accumulators). Pepper is the second crop after tomato produced in greenhouses of Turkey and high-quality yield is the most critical issue in pepper cultivation in greenhouses (Abdel Latef, 2013). Therefore, the present research was implemented to investigate the $\mathrm{Cd}$ accumulation in two pepper (Capsicum annuum L.) cultivars of Solanaceae family. The primary target was to identify the effects of cadmium treatments on plant development and micronutrient compositions of pepper cultivars with different $\mathrm{Cd}$ accumulation levels.

\section{Materials and methods}

\section{Experiment and analyses}

Demre and AT58 pepper cultivars were used as the plant material of this study. The plants were grown under controlled climate conditions $\left(26 / 22{ }^{\circ} \mathrm{C}\right.$ day/night temperature, $16 / 8 \mathrm{~h}$ photoperiod, $350 \mu \mathrm{mol} \mathrm{m} \mathrm{m}^{-2} \mathrm{~s}^{-1}$ light intensity supplied with Osram HQI/2000/D lamps and $65-75 \%$ relative humidity). Surface-sterilized seeds with $1 \%$ (w/v) calcium hypochlorite for $10 \mathrm{~min}$ were rinsed through distilled water. Seeds were then sown in perlite-filled pots and allowed to germinate for 7 days. When the seedlings reached to two true-leaf stage in perlite media (12 days old), they were transferred to $2.7 \mathrm{~L}$ plastic pots (four seedlings per pot) filled with continuously aerated and diluted 1:3 nutrient solution for 2 days to ensure time for plant growth. Thinning was performed then as to have two seedlings in each pot. Nutrient solutions were prepared with distilled water and $2.0 \mathrm{mM} \mathrm{Ca}\left(\mathrm{NO}_{3}\right)_{2}, 0.88 \mathrm{mM} \mathrm{K}_{2} \mathrm{SO}_{4}, 1 \mathrm{mM} \mathrm{MgSO} 4,0.25 \mathrm{mM} \mathrm{KH}_{2} \mathrm{PO}_{4}, 0.1 \mathrm{mM}$ $\mathrm{KCl}, 100 \mu \mathrm{M}$ Fe-EDTA, $10 \mu \mathrm{M} \mathrm{H}_{3} \mathrm{BO}_{3}, 0.5 \mu \mathrm{M} \mathrm{MnSO}_{4}, 1 \mu \mathrm{M} \mathrm{ZnSO}_{4}, 0.2 \mathrm{CuSO}_{4}$ and $0.02 \mu \mathrm{M}\left(\mathrm{NH}_{4}\right)_{6} \mathrm{Mo}_{7} \mathrm{O}_{24}$. Cadmium $\left(3 \mathrm{CdSO}_{4} 8 \mathrm{H}_{2} \mathrm{O}\right)$ was supplemented into nutrient solutions at five-to-six true leaf stage ( 25 days old) of growth for 8 days. All solutions were adjusted as to have a $\mathrm{pH}$ of $6.3 \pm 0.1$. Nutrient solutions were replaced in every 3 4 days throughout the growing period. Leaf chlorophyll contents were identified with the aid of a chlorophyll meter (SPAD-502, Minolta, Japan) before the harvest. The 32day old plants were harvested and at harvest, roots were rinsed through $0.5 \mathrm{mM} \mathrm{CaSO}_{4}$ and de-ionized water for $15 \mathrm{~min}$, and dried at $70^{\circ} \mathrm{C}$ to determine the dry weights.

Dried shoots and roots were ground; wet-digested in a microwave with $2 \mathrm{ml} \mathrm{35 \%}$ $\mathrm{H}_{2} \mathrm{O}_{2}$ and $5 \mathrm{ml} 65 \% \mathrm{HNO}_{3}$. Digested samples were then subjected to elemental analyses for $\mathrm{Cd}, \mathrm{Zn}, \mathrm{Fe}, \mathrm{Mn}$ and $\mathrm{Cu}$ by an inductively coupled plasma optical emission spectrometer ICP-OES; Varian-Vista Pro) device. Measurements were checked with the readings on reference samples of National Institute of Standards and Technology (Gaithersburg, MD, USA). 


\section{Statistical analysis}

Experimental data were subjected to variance analysis in accordance with randomized plots design with 3 replications. Means were compared by least significant difference (LSD) test at 5\% probability level.

\section{Results and discussion}

\section{Dry matter yields, SPAD readings and cadmium in shoots and roots}

Cadmium treatment $(15 \mu \mathrm{M})$ reduced shoot dry matter yield by $37 \%$ in AT58 cultivar and by $48 \%$ in Demre cultivar and reductions in root dry matter yields were respectively observed as 21 and $29 \%$ (Table 1). Cd-induced regress in plant growth was also reported for wheat (Naeem, 2016), tomatoes (Kumar et al., 2015), sunflower (Azevedo et al., 2005) and pepper (Abdel Latef, 2013). In this study, more chlorosis and necrotic patches were observed over the oldest leaves of Demre cultivar than the leaves of AT58 at $15 \mu \mathrm{M}$ Cd dose. Root browning degrees were also greater in Demre cultivar than in AT58 under Cd treatments. Generally, reduced root elongation (Dong et al., 2005) and browning (Liu et al., 1995) are the initial symptoms for cadmium toxicity in roots and chlorosis and rolling are the initial symptoms for cadmium toxicity in shoots (Weigel and Jäger, 1980).

SPAD values significantly decreased with $\mathrm{Cd}$ treatment in both cultivars and the decrease rates with $15 \mu \mathrm{M}$ Cd treatment were found to be $15 \%$ in AT58 and $30 \%$ in Demre cultivar (Table 1). Sandalio et al. (2001) indicated the reason of Cd-induced reductions in chlorophyll content as chlorophyll degradation or destructions in chlorophyll biosynthesis and membrane integrity.

Table 1. Effects of cadmium $(-C d=0$ and $+C d=15 \mu M)$ treatments on shoot-root dry weights and SPAD values of AT 58 and Demre pepper cultivars

\begin{tabular}{|c|c|c|c|c|c|c|}
\hline \multirow{3}{*}{ Cultivars } & \multicolumn{4}{|c|}{ Dry matter yields $\left(\text { mg plant }^{-1}\right)^{*}$} & \multirow{2}{*}{\multicolumn{2}{|c|}{ SPAD values }} \\
\hline & \multicolumn{2}{|c|}{ Shoot } & \multicolumn{2}{|c|}{ Root } & & \\
\hline & - Cd & $+\mathbf{C d}$ & - Cd & $+\mathbf{C d}$ & - Cd & $+\mathbf{C d}$ \\
\hline AT58 & $1139 \mathrm{aA}$ & $723 \mathrm{bA}$ & $154 \mathrm{aB}$ & $122 \mathrm{bB}$ & $53 \mathrm{aA}$ & $45 \mathrm{bA}$ \\
\hline Demre & $1240 \mathrm{aA}$ & $643 \mathrm{bA}$ & $234 \mathrm{aA}$ & $167 \mathrm{bA}$ & $42 \mathrm{aB}$ & $30 \mathrm{bB}$ \\
\hline
\end{tabular}

*Means indicated with different small letters (between Cd treatment, in each cultivar) and by the same capital letters (between cultivars, in each $\mathrm{Cd}$ treatment) are significantly different at $\mathrm{p}<0.05$

Cadmium treatment $(15 \mu \mathrm{M})$ significantly increased shoot $\mathrm{Cd}$ concentrations and contents of both cultivars (Table 2). Demre had higher shoot Cd concentration and content than AT58. While shoot Cd concentration and content of Demre cultivar at $15 \mathrm{mM} \mathrm{Cd}$ treatment were $148 \mathrm{mg} \mathrm{kg}^{-1} \mathrm{DW}$ and $95.1 \mu \mathrm{g}$ plant $^{-1}$, the values in AT58 cultivar were $90.5 \mathrm{mg} \mathrm{kg}^{-1} \mathrm{DW}$ and $65.1 \mu \mathrm{g}$ plant ${ }^{-1}$, respectively. Root Cd concentrations and contents of AT58 were greater than Demre (Table 2). Root Cd concentration and content of AT 58 were respectively measured as $1529.7 \mathrm{mg} \mathrm{kg}^{-1} \mathrm{DW}$ and $186.8 \mu \mathrm{g} \mathrm{plant}^{-1}$. For both cultivars, roots had greater $\mathrm{Cd}$ concentrations and contents than the shoots (Table 2). Cataldo et al. (1983) pointed out that large portion of cadmium retained in plant roots and a small portion was transferred to shoots. Blum (1997) reported the greatest Cd content for roots and the least Cd content for seeds; 
stem, leaves and fruits were placed in between them. Regardless of the concentrations, both cultivars differ in their root and shoot $\mathrm{Cd}$ accumulation capacity. Although root $\mathrm{Cd}$ contents were not influenced significantly by cadmium treatments, high root Cd content of AT58 than Demre was found to be compatible with root $\mathrm{Cd}$ concentrations of these cultivars (Table 2). Previous researches tried to explain the differences in Cd-tolerance of plants with the differences in their Cd-uptake and accumulation levels (Hall, 2002; Kochian et al., 2002). Complying with these hypotheses, AT58 cultivar of the present study had greater root $\mathrm{Cd}$ concentration and smaller shoot $\mathrm{Cd}$ concentration than Demre cultivar. Such findings indicated that AT58 cultivar retained greater Cd quantities in roots.

Table 2. Effects of cadmium $(-C d=0$ and $+C d=15 \mu M)$ treatments on shoot-root $C d$ concentration and content of AT58 and Demre pepper cultivars

\begin{tabular}{|c|c|c|c|c|c|c|c|c|}
\hline \multirow{3}{*}{ Cultivars } & \multicolumn{4}{|c|}{ Cd concentrations $\left(\mathrm{mg} \mathrm{kg}^{-1} \mathrm{DW}\right)^{*}$} & \multicolumn{4}{|c|}{ Cd contents $\left(\mu \mathrm{g}\right.$ plant $\left.^{-1}\right)$} \\
\hline & \multicolumn{2}{|c|}{ Shoot } & \multicolumn{2}{|c|}{ Root } & \multicolumn{2}{|c|}{ Shoot } & \multicolumn{2}{|c|}{ Root } \\
\hline & - Cd & $+\mathbf{C d}$ & - Cd & $+\mathbf{C d}$ & - Cd & $+\mathbf{C d}$ & - Cd & $+\mathbf{C d}$ \\
\hline AT58 & $0.3 \mathrm{bA}$ & $90.5 \mathrm{aB}$ & $2.9 \mathrm{bA}$ & $1529.7 \mathrm{aA}$ & $0.4 \mathrm{bA}$ & $65.1 \mathrm{aB}$ & $0.5 \mathrm{bA}$ & $186.8 \mathrm{aA}$ \\
\hline Demre & $0.4 \mathrm{bA}$ & $148.0 \mathrm{aA}$ & $3.7 \mathrm{bA}$ & $1036.1 \mathrm{aB}$ & $0.5 \mathrm{bA}$ & $95.1 \mathrm{aA}$ & $0.9 \mathrm{bA}$ & $173.0 \mathrm{aA}$ \\
\hline
\end{tabular}

*Means indicated with different small letters (between Cd treatment, in each cultivar) and by the same capital letters (between cultivars, in each Cd treatment) are significantly different at $\mathrm{p}<0.05$

\section{Shoot and root micronutrients}

Cadmium treatment $(15 \mu \mathrm{M})$ significantly decreased $(\mathrm{p}<0.05)$ shoot $\mathrm{Zn}, \mathrm{Mn}, \mathrm{Cu}$ and $\mathrm{Fe}$ concentrations and contents of both cultivars (Table 3). Shoot $\mathrm{Zn}, \mathrm{Mn}, \mathrm{Cu}$ and Fe concentrations of AT58 cultivar decreased with Cd treatment at slightly greater rates than at Demre cultivar. The average Cd-induced decrease was $55 \%$ for $\mathrm{Zn}$ and $\mathrm{Mn}$ and $69 \%$ for $\mathrm{Fe}$ and $\mathrm{Cu}$ (Table 3). Cd-treatment also reduced root $\mathrm{Zn}$ and $\mathrm{Mn}$ levels significantly. Cd treatments reduced $\mathrm{Zn}$ and $\mathrm{Mn}$ levels of wheat root and shoots, but did not influence shoot and root $\mathrm{Fe}$ and $\mathrm{Cu}$ levels (Jalil et al., 1994). Cadmium toxicity mostly comes from the interactions of $\mathrm{Cd}$ with the other essential nutrients, especially with the same valence (Skrebsky et al., 2008). In a hydroponic experiment with barley, $\mathrm{Cd}$ treatments significantly decreased root and shoot $\mathrm{Zn}, \mathrm{Cu}$ and $\mathrm{Mn}$ concentrations and shoot Fe concentrations (Wu et al., 2003).

In the present study, while root $\mathrm{Cu}$ content of AT58 decreased significantly with $\mathrm{Cd}$ treatment, root $\mathrm{Cu}$ content of Demre and root $\mathrm{Cu}$ concentrations of both cultivars did not change (Table 3). Iron concentration and accumulation in roots of spinach was not affected by Cd treatments (Abul Kashem and Kawai, 2007). Similar with those findings, present root $\mathrm{Fe}$ concentrations and contents of both pepper cultivars remained unchanged with Cd supply (Table 3). Kabata-Pendias and Pendias (2001) indicated strong bonds of $\mathrm{Cu}$ and $\mathrm{Fe}$ in root cells.

Present differences in shoot $\mathrm{Zn}$ and $\mathrm{Cu}$ levels were mostly attributed to $\mathrm{Cd}$-induced regress in plant growth and development. Thusly, shoot $\mathrm{Zn}$ and $\mathrm{Cu}$ concentrations were not significantly different (Table 3). Similarly, shoot Fe and Mn concentrations-contents were not also significantly different at $15 \mu \mathrm{M}$ Cd treatment (Table 3). Under Cd supply, there seems to be antagonistic relationships between root $\mathrm{Cd}$ concentrations-contents and root $\mathrm{Zn}$ concentrations-contents (Table 3). Under controlled conditions, Demre 
cultivar generally had greater quantities of $\mathrm{Zn}, \mathrm{Fe}, \mathrm{Mn}$ and $\mathrm{Cu}$ than AT58 cultivar (Table 3). Such a case may result in significantly different $\mathrm{Zn}$ and $\mathrm{Cu}$ accumulation levels under $\mathrm{Cd}$ supply. Differences in cultivars may be related to present $\mathrm{Cd}$ dose, exposure duration to this dose and micronutrient levels of the cultivars under controlled conditions.

Table 3. Effects of cadmium ( $-\mathrm{Cd}=0$ and $+C d=15 \mu \mathrm{M})$ treatments on shoot-root $\mathrm{Zn}, \mathrm{Fe}$, $M n$ and Cu concentration and content of AT 58 and Demre pepper cultivars

\begin{tabular}{|c|c|c|c|c|c|c|c|c|}
\hline \multirow{3}{*}{ Cultivars } & \multicolumn{2}{|c|}{$\mathbf{Z n}$} & \multicolumn{2}{|c|}{$\mathbf{F e}$} & \multicolumn{2}{|c|}{ Mn } & \multicolumn{2}{|c|}{$\mathbf{C u}$} \\
\hline & - Cd & $+\mathrm{Cd}$ & - Cd & $+\mathrm{Cd}$ & - Cd & $+\mathbf{C d}$ & - Cd & $+\mathbf{C d}$ \\
\hline & \multicolumn{8}{|c|}{ Shoot concentrations $\left(\mathrm{mg} \mathrm{kg}^{-1} \mathrm{DW}\right)^{*}$} \\
\hline AT58 & $36.2 \mathrm{aB}$ & $15.2 \mathrm{bB}$ & $175.0 \mathrm{aA}$ & $51.1 \mathrm{bA}$ & $26.6 \mathrm{aB}$ & $11.1 \mathrm{bA}$ & $8.3 \mathrm{aA}$ & $2.4 \mathrm{bB}$ \\
\hline \multirow[t]{2}{*}{ Demre } & $41.1 \mathrm{aA}$ & $19.6 \mathrm{bA}$ & $215.1 \mathrm{aA}$ & $66.0 \mathrm{bA}$ & $31.5 \mathrm{aA}$ & $14.4 \mathrm{bA}$ & $9.1 \mathrm{aA}$ & $3.2 \mathrm{bA}$ \\
\hline & \multicolumn{8}{|c|}{ Root concentrations $\left(\mathrm{mg} \mathrm{kg}^{-1} \mathrm{DW}\right)$} \\
\hline AT58 & $101.3 \mathrm{aA}$ & $54.7 \mathrm{bB}$ & $976.0 \mathrm{aA}$ & $1032.1 \mathrm{aA}$ & $112.1 \mathrm{aA}$ & $11.0 \mathrm{bA}$ & $36.0 \mathrm{aA}$ & $35.8 \mathrm{aA}$ \\
\hline \multirow[t]{2}{*}{ Demre } & $100.8 \mathrm{aA}$ & $66.7 \mathrm{bA}$ & $708.0 \mathrm{aA}$ & $734.1 \mathrm{aB}$ & $49.8 \mathrm{aB}$ & $7.0 \mathrm{bB}$ & $31.0 \mathrm{aA}$ & $33.6 \mathrm{aA}$ \\
\hline & \multicolumn{8}{|c|}{ Shoot content $\left(\mu\right.$ plant $\left.^{-1}\right)$} \\
\hline AT58 & $41.0 \mathrm{aA}$ & $11.0 \mathrm{bA}$ & $199.3 \mathrm{aA}$ & $37.0 \mathrm{bA}$ & $30.2 \mathrm{aB}$ & $8.0 \mathrm{bA}$ & $9.5 \mathrm{aA}$ & $1.7 \mathrm{bA}$ \\
\hline \multirow[t]{2}{*}{ Demre } & $51.2 \mathrm{aA}$ & $12.6 \mathrm{bA}$ & $266.2 \mathrm{aA}$ & $42.4 \mathrm{bA}$ & $39.2 \mathrm{aA}$ & $9.2 \mathrm{bA}$ & $11.3 \mathrm{aA}$ & $2.1 \mathrm{bA}$ \\
\hline & \multicolumn{8}{|c|}{ Root content $\left(\mu g\right.$ plant $\left.^{-1}\right)$} \\
\hline AT58 & $15.5 \mathrm{aB}$ & $6.7 \mathrm{bB}$ & $150.6 \mathrm{aA}$ & $126.5 \mathrm{aA}$ & $17.2 \mathrm{aA}$ & $1.4 \mathrm{bA}$ & $5.5 \mathrm{aA}$ & $4.4 \mathrm{bB}$ \\
\hline Demre & $23.3 \mathrm{aA}$ & $11.1 \mathrm{bA}$ & $169.7 \mathrm{aA}$ & $122.6 \mathrm{aA}$ & $12.0 \mathrm{aA}$ & $1.2 \mathrm{bA}$ & $7.3 \mathrm{aA}$ & $5.6 \mathrm{aA}$ \\
\hline
\end{tabular}

*Means, indicated with different small letters (between $\mathrm{Cd}$ treatment, in each cultivar) and by the same capital letters (between cultivars, in each Cd treatment) are significantly different at $\mathrm{p}<0.05$

\section{Conclusion}

Cadmium treatment generated significant decreases in both root and shoot dry matter yields. Such decreases were greater in Demre cultivar than in AT58 cultivar. Similarly, greater decreases were observed in SPAD values of Demre cultivar than of AT58 cultivar with $\mathrm{Cd}$ treatment. Regardless of shoot $\mathrm{Cd}$ uptake and accumulation, it was observed that there were differences in Cd toxicity tolerance of the cultivars, but these differences were not attributed to differences in microelement uptake and transport of the cultivars. For Cd-polluted sites, AT58 can be recommended to reduce yield losses. Further studies are recommended to compare antioxidative defense mechanisms of AT58 and Demre pepper cultivars with different root and shoot Cd accumulation levels.

Conflict of interests. The author has not declared any conflict of interests.

\section{REFERENCES}

[1] Abdel Latef, A. A. (2013): Growth and some physiological activities of pepper (Capsicum annuum L.) in response to cadmium stress and mycorrhizal symbiosis. Journal of Agricultural Science and Technology 15: 1437-1448.

[2] Abul Kashem, M. D., Kawai, S. (2007): Alleviation of cadmium phytotoxicity by magnesium in Japanese mustard spinach. - Soil Science and Plant Nutrition 53: 246-251.

[3] Allen, S. E. (1989): Chemical Analyses of Ecological Material. 2 ${ }^{\text {nd }}$ Ed. - Blackwell Scientific, London. 
[4] Alloway, B. J., Steinnes, E. (1999): Anthropogenic Additions of Cadmium to Soils. - In: McLaughlin, M. J., Singh, B. R. (eds.) Cadmium in Soils and Plants. Kluwer Academic Publishers, Dordrecht, pp. 97-123.

[5] Azevedo, H., Gomes, C., Pinto, G., Fernandes, J., Loureiro, S., Santos, C. (2005): Cadmium effects on sunflower growth and photosynthesis. - Journal of Plant Nutrition 28: 2211-2220.

[6] Benavides, M. P., Gallego, S. M., Tomaro, M. L. (2005): Cadmium toxixity in plants. Brazilian Journal of Plant Physiology 17: 21-34.

[7] Bhandal, I. S., Kuar, H. (1992): Heavy metal inhibition of nitrate uptake and in vivo nitrate reductase in roots of wheat (Triticum aestivum L.). - Indian Journal of Plant Physiology 35: 281-284.

[8] Blum, W. H. (1997): Cadmium uptake by higher plants. - Proceedings of extended abstracts from the Fourth International Conference on the Biogeochemistry of Trace Elements, Berkeley, USA, University of California, pp. 109-110.

[9] Cataldo, D. A., Garland, T. R., Wildung, R. E. (1983): Cadmium uptake kinetics in intact soybean plants. - Plant Physiology 73: 844-848.

[10] Clarkson, D. T., Luttge, U. (1989): Mineral nutrition - divalent cations, transport and compartmentalization. - Progress in Botany 51: 93-112.

[11] Dong, J., Wu, F., Zhang, G. (2005): Effect of cadmium on growth and photosynthesis of tomato seedlings. - Journal of Zhejiang University Science B 6: 974-980. DOI: 10.1631/ jzus.2005.B0974.

[12] Ekmekci, Y., Tanyolac, D., Ayhan, B. (2008): Effects of cadmium on antioxidant enzyme and photosynthetic activities in leaves of two maize cultivars. - Journal of Plant Physiology 165: 600-611.

[13] Gussarsson, M. (1994): Cadmium-induced alterations in nutrient composition and growth of Betula pendula seedlings: The significance of fine roots as a primary target for cadmium toxicity. - Journal of Plant Nutrition 17: 2151-2163.

[14] Hall, J. L. (2002): Cellular mechanisms for heavy metal detoxification and tolerance. Journal of Experimental Botany 53: 1-11.

[15] Hussain, M. M., Saeed, A., Khan, A. A., Javid, S., Fatima, B. (2015): Differential responses of one hundred tomato cultivars grown under cadmium stress. - Genetics and Molecular Research 14: 13162-13171. https://doi.org/10.4238/2015.October.26.12.

[16] Jalil, A., Selles, F., Clarke, J. M. (1994): Effect of cadmium on growth and the uptake of cadmium and other elements by durum wheat. - Journal of Plant Nutrition 17(11): 18391858.

[17] Jibril, S. A., Hassan, S. A., Ishak, C. F., Megat Wahab, P. E. (2017): Cadmium toxicity affects phytochemicals and nutrient elements composition of lettuce (Lactuca sativa L.). - Advances in Agriculture Article ID 1236830. https://doi.org/10.1155/2017/1236830.

[18] Kabata-Pendias, A., Pendias, H. (2001): Trace Elements in Soils and Plants. 3rd Ed. CRC Press, Boca Raton, FL.

[19] Khan, N. A., Samiullah, S. S., Nazar, R. (2007): Activities of antioxidative enzymes, sulphur assimilation, photosynthetic activity and growth of wheat (Triticum aestivum) cultivars differing in yield potential under cadmium stress. - Journal of Agronomy and Crop Science 193(6): 435-444. DOI: 10.1111/j.1439-037X.2007.00272.x.

[20] Kloke, A., Sauerbeck, D. C., Vetter, H. (1984): The Contamination of Plants and Soils with Heavy Metals and the Transport of Metals in Terrestrial Food Chains. - In: Nriagu, J. O. (ed.) Changing Metal Cycles and Human Health. Dahlem Konferenzen, Berlin, pp 113-141.

[21] Kochian, L. V., Pence, N. S., Letham, D. L. D., Pineros, M. A., Magalhaes, J. V., Hoekenga, O. A., Garvin, D. F. (2002): Mechanisms of metal resistance in plants: aluminum and heavy metals. - Plant and Soil 247: 109-119.

[22] Kuboi, T., Noguchi, A., Yazaki, J. (1986): Family-dependent cadmium accumulation characteristics in higher plants. - Plant and Soil 92: 405-415. 
[23] Kumar, P., Edelstein, M., Cardarelli, M., Ferri, E., Colla, G. (2015): Grafting affects growth, yield, nutrient uptake, and partitioning under cadmium stress in tomato. Hortscience 50: 1654-1661.

[24] Li, S. L, Wang, H. X., Wu, Y. S. (1990): Antagonistic effect of zinc on cadmium in water hyacinth. - Acta Scientiae Circumstantiae 10: 244-249.

[25] Liu, D., Jiang, W., Wang, W., Zhai, L. (1995): Evaluation of metal ion toxicity on root tip cells by the Allium test. - Israel Journal of Plant Science 43: 125-33.

[26] Mitchell, L., Grant, C., Racz, G. (2000): Effect of nitrogen application of concentration of concentration of cadmium and nutrient ions in soil solution and in durum wheat. Canadian Journal of Soil Science 80: 107-115. http://dx.doi.org/10.4141/S98-085.

[27] Naeem, A., Saifullah, Rehman, M. Z. U., Akhtar, T., Ok, Y. S., Rengel, Z. (2016): Genetic variation in cadmium accumulation and tolerance among wheat cultivars at the seedling stage. - Communication of Soil Science and Plant Analysis. http://dx.doi.org/10.1080/00103624.2016.1141918.

[28] Nan, Z., Li, J., Zhang, J., Cheng, G. (2002): Cadmium and zinc interactions and their transfer in soil crop system under actual field conditions. - Science of the Total Environment 285: 187-195.

[29] Obata, H., Umebayashi, M. (1997): Effects of cadmium on mineral nutrient concentrations in plants differing in tolerance for cadmium. - Journal of Plant Nutrition 20(1): 97-105.

[30] Rivetta, A., Negrini, N., Cocucci, M. (1997): Involvement of $\mathrm{Ca}^{2+}$-calmodulin in $\mathrm{Cd}^{2+}$ toxicity during the early phases of radish (Raphanus sativus L.) seed germination. - Plant Cell Environment 20: 600-608.

[31] Sandalio, L. M., Dalurzo, H. C., Gomez, M., Romero-Puertas, M. C., del Rio, L. A. (2001): Cadmium-induced changes in the growth and oxidative metabolism of pea plants. - Journal of Experimental Botany 52: 2115-2126.

[32] Sarwar, N, Saifullah, M. S. S., Zia, M. H., Naeem, A., Bibi, S., Farid, G. (2010): Role of mineral nutrition in minimizing cadmium accumulation by plants. - Journal of the Science of Food and Agriculture 90: 925-937. DOI: 10.1002/jsfa.3916.

[33] Sengar, R. S., Gautam, M., Sengar, R. S., Garg, S. K., Sengar, K., Chaudhary, R. (2008): Lead stress effects on physiobiochemical activities of higher plants. - Reviews of Environmental Contamination and Toxicology 196: 73-93.

[34] Shamsi, I. H., Wei, K., Zhang, G. P., Jilani, G., Hassan, M. J. (2008): Interactive effects of cadmium and aluminum on growth and antioxidative enzymes in soybean. - Biologia Plantarum 52: 165-169.

[35] Skrebsky, E. C., Tabaldi, L. A., Pereira, L. B., Rauber, R., Maldaner, J., Cargnelutti, D., Gonçalves, J. F., Castro, G. Y., Schetinger, M. R. C., Nicoloso, F. T. (2008): Effect of cadmium on growth, micronutrient concentration, and $\delta$-aminolevulinic acid dehydratase and acid phosphatase activities in plants of Pfaffia glomerata. - Brazilian Journal of Plant Physiology 20: 285-294.

[36] Tiryakioglu, M., Eker, S., Ozkutlu, F., Husted, S., Cakmak, I. (2006): Antioxidant defense system and cadmium uptake in barley cultivars differing in cadmium tolerance. Journal of Trace Elements in Medicine and Biology 20: 181-189.

[37] Wang, M., Zou, J., Duan, X., Jiang, W., Liu, D. (2007): Cadmium accumulation and its effects on metal uptake in maize (Zea mays L.). - Bioresource Technology 98: 82-88.

[38] Weigel, H. J., Jäger, H. J. (1980): Subcellular distribution and chemical form of cadmium in bean. - Plant Physiology 65: 480-482.

[39] Wu, F., Zhang, G., Yu, J. (2003): Interaction of cadmium and four microelements for uptake and translocation in different barley cultivars. - Communications in Soil Science and Plant Analysis 34(13-14): 2003-2020.

[40] Xin, J., Huang, B., Liu, A., Zhou, W., Liao, K. (2013): Identification of hot pepper cultivars containing low $\mathrm{Cd}$ levels after growing on contaminated soil: uptake and redistribution to the edible plant parts. - Plant and Soil 373: 415-425. 
[41] Yang, X., Baligar, V. C., Martens, D. C., Clark, R. B. (1996): Cadmium effects on influx and transport of mineral nutrients in plant species. - Journal of Plant Nutrition 19(3-4): 643-656.

[42] Yang, X. E., Long, X. X., Ye, H. B., He, Z. L., Calvert, D. V., Stoffella, P. J. (2004): Cadmium tolerance and hyperaccumulation in a new Zn hyperaccumulating plant species (Sedum alfredii $\mathrm{H}$.). - Plant and Soil 259: 181-189.

[43] Yildiz, N. (2005): Response of tomato and corn plants to increasing Cd levels in nutrient culture. - Pakistan Journal of Botany 37(3): 593-599.

[44] Zhang, J. B., Huang, W. N. (2000): Advances on physiological and ecological effects of cadmium on plants. - Acta Ecologica Sinica 20: 514-523 (in Chinese).

[45] Zhou, W. B., Qiu, B. S. (2005): Effects of cadmium hyperaccumulation on physiological characteristics of Sedum alfredii Hance (Crassulaceae). - Plant Science 169: 737-745. 